\title{
Okul Öncesi Dönemdeki Korunmaya Muhtaç Çocukların Ahlâki Değer Yapılarının Çocuklara İlişkin Bazı Değişkenlere Göre İncelenmesi: Ankara Örneklemi*
}

Investigation of Moral Value Structures of 6172 Months old Indigent Children According to Some Variables: The Case of Ankara**

Elif YORGUN YASAR, Sorumlu Yazar, Öğretmen.

Aile, Çalışma ve Sosyal Hizmetler Bakanlığı.

E-mail: yorgun1992@hotmail.com

ORGID: 0000-0002-5430-9201

Saide ÖZBEY, Doç. Dr.

Gazi Üniversitesi, Gazi Eğitim Fakültesi.

E-mail: saideozbey@gmail.com,sozbey@gazi.edu.tr

ORCID: 0000-0001-8487-7579

ISSN: 1303-880X

e-ISSN: 2667-7504

http://ded.dem.org.tr

Geliş/Received: 06.03.2018

Kabul/Accepted: 29.06 .2019

Makale Yayın: 25.12.2019

Makale Türü/Article Type:

Araştırma/Research
Attf/Citation: Yorgun Yasar, E. \& Özbey, S. (2019). Okul öncesi dönemdeki korunmaya muhtaç çocukların ahlaki değer yapılarının çocuklara ilişkin bazı değişkenlere göre incelenmesi: Ankara örneklemi. Değerler Eğitimi Dergisi, 17 (38), 41-70. DOI: 10.34234/ded.402313

* Bu çalışma, Gazi Üniversitesi Eğitim Bilimleri Enstitüsü bünyesinde Doç.Dr. Saide Özbey danışmanlığında Elif Yorgun Yasar'ın yüksek lisans çalışmasından üretilmiştir.

** This research makes up a part of the post graduate study presented by Elif Yorgun Yasar under the counseling of the Assoc. Prof. Saide Özbey in Gazi University, Institute of Education Sciences. 
Öz: Araştırma okul öncesi eğitim kurumuna devam eden korunmaya muhtaç olan 61- 72 aylık çocukların ahlaki değer yapılarının kurum ile ilgili bazı değişkenlere göre incelenmesi amacıyla yapılmıştır. Bu değişkenler kurumda kalma süresi, aile yanına izinli gitme durumu, yakınları tarafından ziyaret edilme durumu, kardeşleriyle birlikte/ayrı olma durumu ve korunma altına alınma nedeni olarak ele alınmıştır. Araştırmada "Genel Bilgi Formu (Korunmaya muhtaç olan çocuklarla ilgili)" ve "Ahlaki Değer Yapısını Belirleme Ölçeği”" kullanılımıştır. Araştırmanın evrenini 2015- 2016 eğitim-öğretim yılında Ankara ilinde çocuk evlerinde kalan 61-72 aylık korunmaya muhtaç çocuklar oluşturmaktadır. Araştırmanın çalışma grubuna Ankara ilinde çocuk evlerinde kalan 61- 72 aylık korunmaya muhtaç olan bütün çocuklar dahil edilmiştir $(\mathrm{N}=48)$. Verilerin analizinde; cinsiyetlerine, aileleri yanına izinli gitme durumlarına, aileleri tarafından ziyaret edilme durumlarına ve kardeşleriyle ayrı/birlikte olma durumlarına göre karşılaştırılmasında Mann Whitney U testi; kardeş sayılarına, kurumda kalma nedenine ve kurumda kalma süresine göre karşılaştırılmasında Kruskal Wallis testi kullanılmıştır. Araştırma sonucuna göre, korunmaya muhtaç çocukların ahlaki değer yapısı belirleme ölçeğinden aldıkları puanlar arasında; aile yanına izinli gitme durumu ve korunma altına alınma nedeni değişkenlerine göre anlamlı bir farklılık olmadığı saptanmıştır ( $p>0,05)$. Kurumda kalma süresi, kardeşleriyle birlikte/ ayrı olma durumu ve yakınları tarafından ziyaret edilme durumu değişkenlerine göre anlamlı bir farkl1lık olduğu sonucuna ulaşılmıştır $(p<0,05)$.

Anahtar Sözcükler: Okul öncesi eğitim, Çocuk, Ahlaki değer, Korunmaya muhtaç çocuk, Çocuk evleri.

$\&$

Abstract: The study was conducted to investigate the moral value structures of 61- 72 months old indigent children continuing their education in preschool institutions, according to some variables related to the institution. These variables are considered as; the duration of stay in the institution, permission to visit the family, visitation by their relatives, being with or being separated with their siblings, and protective factors all are taken into consideration. In the research, "General Information Form (about children in need of protection)" and "Moral Value Structure Determination Scale" were used. The universe of the study consists of 61-72 months old children in need of protection in the Children's Homes in Ankara in the 2015-2016 academic year. The study group of the research 
included all 61-72 months children in need of protection living in Children's Homes in Ankara $(\mathrm{N}=48)$. In the analysis of the data; gender, being allowed to visit their families, being visited by their relatives, being with their siblings / being separated with their siblings variables will be compared via Mann Whitney $\mathrm{U}$ test. Kruskal Wallis test was used to compare the number of siblings, reason of stay and duration of stay in the institution. According to the results of the study, the scores the children obtained from Moral Value Structure Determination indicate that there was no significant difference between the variables of being allowed to visit their families and the reason for being under protection. $(p>0.05)$. It was concluded that there was a significant difference in terms of the variables of duration of stay in the institution, being with or being separated from siblings and visitation by relatives $(\mathrm{p}<0.05)$.

Keywords: Preschool education, Children, Moral value, Children in need of protection, Child safe homes.

\section{Giriş}

Toplumsal yapı ve onu oluşturan toplumsal ilişkiler süreç içinde değişime uğramaktadır. Yaşamın her alanının değişmesi ile birlikte insanların amaçları, inançları, değer yargıları, sanat anlayışları da değişmektedir. Topluma uyum sağlama çabasında olan birey, bu değişimlerden etkilenmektedir. Birey, içinde bulunduğu değişen toplumun gelenek görenek, ahlak gibi değerlerini içselleştirerek o toplumun bir parçası haline gelmektedir. Toplumun küçük bireyi olan çocuk, içinde bulunduğu çevreden, girdiği ortamlardan, iletişim halinde olduğu kişilerden, aldığ 1 eğitimden etkilenmektedir. Bu içselleştirme ve uyum sağlama çabası sonucunda çocuğun sahip olduğu değerlerin toplumsal değerler ile paralel olması beklenmektedir. Toplumun kabul edebildiği, çocuğun topluma uyumunun sağlanmasında yapması ve yapmaması gereken kurallar içerisinde iyi insan özelliklerini taşıyabilmesi, değer olarak tanımlanmaktadır. Değerler ve davranışlar bir bütün olarak ele alınır. İnsan içinde bulunduğu toplumun değer yargılarından etkilenirken, davranışları doğrultusunda da toplumdan takdir görmek istemektedir. Sevgi, sayg1, dürüstlük, nezaket, temizlik vb. değerler toplum tarafindan onay verilen değerlerdir ve bu değerlere sahip olan birey toplumda değer görmeyi beklemektedir. İçinde yaşadığı topluma ayak uydurup uyduramaması ise ahlaki gelişim düzeyini yansıtmaktadır (Arabacı ve Akgül, 2013; Dirican, 2013; Özbey, 2012; Öztürk, 2011; Sağ, 2003; Yazıc1, 2013; Yörükoğlu, 2007). 
Maslow, insanın değerlerine göre önceliklerini belirlediğini, amaçlı uzun vadeli faaliyetlerini değerlerine göre düzenlediğini ve bu sebeple de insanın bir değerler hiyerarşisine sahip olması gerektiğini savunmaktadır. En temel değer grubunu ise "ahlaki değerler" olarak ele almaktadır (Aydın, 2006). Bireyin, toplumun ve insanlığın gelişmesi, diğer değerlerin yanında özellikle ahlaki değerlere dayanmaktadır. Ahlaki değerler olumlu hedef göstererek davranış imkânı sağlamakta ve toplumdan ayrı tutulamamaktadır. Dolayısıyla toplumla iç içe olan insanın, bulunduğu toplumu etkileyen ahlaki kurallardan ayrı olması düşünülmemektedir. Ahlaken alt seviyelerde kalmış bireyler bu dengeyi kuramamakta ve toplumsal değer yargıları doğrultusunda hareket edememektedir. $\mathrm{Bu}$ insanlar toplumda dışlanmakta ve sağlıklı bir kişilik yapısı gösterememektedirler (Çağdaş ve Şahin, 2002; Çalışkur, 2010; Öztürk, 2003).

Toplumu oluşturan insanın kişilik sahibi olabilmesi ancak değerlerle mümkün olabilmektedir. Bunun nedeni değerlerin insanın içinde kök salmış olmasıdır. İnsanın küçük yaşlardan itibaren toplum içinde iyi ve doğru davranışı öğrenerek yapması, ileri dönemlerde topluma uygun ahlaki davranışlar sergilemesinin temeli olacaktır ve çocukluk dönemi temel değerlerin kazanımı konusunda en verimli dönemdir. Okul öncesi eğitimi ile çocuklar paylaşmayı, dayanışmayı, sosyalleşmeyi, birlikte çalışmayı öğrenmektedirler. Bununla birlikte dürüstlük, azimli olma, yardımsever olma, kendine güven, saygı, işbirliği gibi birçok ahlaki değerin kazanılması okul öncesi eğitimle hedeflenmektedir. Bu hedef doğrultusunda eğitimci, çocuklara sürekli olarak ahlaki mesajlar iletmektedir. Küçük çocukların bilişsel yapıları, kuralları ve ahlak ilkelerini anlamlandırma konusunda yeterli değildir. Çocuklar için soyut olan ahlaki kurallar ve kavramlar, eylemlerle ve somut yollarla açiklanarak benimsetilmesi gerekmektedir. Çocukların bu kurallara uyumu ve davranışları ahlaki değerlerini ortaya koymaktadır. Gerçekleştirdikleri davranışın sonucuna ve aldıkları tepkiye göre davranışın iyi veya kötü olduğunu anlamlandırmaktadırlar. Ailelerin, eğitimcilerin, çevrenin bu konuda duyarlı olarak çocukların en iyi şekilde geleceğe hazırlanma sorumluluklarının kendilerinde olduğu bilincinde olmaları gerekmektedir. Bu bilinç doğrultusunda toplumsal değerlere uygun rol modellerini çocuklara sergileyerek onların toplumun birer parçası olması yönünde yol gösterici konumunda olacaklardır (Arabacı ve Akgül, 2013; Aydın, 2006; Aydın ve Gürler, 2014; Balat, 2012; Çağdaş ve Şahin, 2002; Çalışkur, 2010; Gül, 2013; Karatay, 2011; Kozan, 2012; Sapsağlam, 2016; Senemoğlu, 2015; Yaka, Yalçın ve Denizli, 2014). 
Değer eğitiminin ilk başladığı kurum ise ailedir. Aile, çocuk için davranış biçimi kazanmasında, değerleri tanımasında, içselleştirmesinde eşsiz bir eğitim yeridir. Çocuğun kişilik gelişimini destekleyerek sağlam temellere yerleştirmek, sahip olduğu kültürel değerleri ile çocuğun davranış kalıplarını şekillendirmek ailenin işlevleri arasındadır. Çocuk içinde bulunduğu ailenin ahlak çerçevesi içinde yetişecek ve ailenin içinde bulunduğu toplumun ahlak kurallarını benimseyecektir. Çocuğun hangi değerlere sahip olup olmadığını bilerek çocuğa o doğrultuda rehberlik yapma görevini aile üstlenmektedir. Doğruluk, büyüklere saygı, görgü kurallarına uyma, küçüklere ve güçüzlere yardım, adil olma ve hak gözetme gibi değerlerin benimsenmesinde aile etkili bir şekilde devreye girmektedir. Aile ortamını sağlıklı ve sağlıksız ortamlar şeklinde değerlendirdiğimizde, sağlıklı aile ortamında büyüyen çocukların kendi doğrularını daha iyi dile getirebilen, kendisini savunabilen, duygu ve davranışlarının daha farkında olan çocuklar olurken, sağlıksız ailede büyüyen çocuklar dıştan denetimli bireyler olarak yetişmektedirler (Aydın, 2006; Beil, 1996; Kozan, 2012; Milli Eğitim Bakanlı̆̆ı, 2013; Öztürk, 2011; Sapsağlam, 2016; Terzi, 2009; Yazıc1, 2013; Yörükoğlu, 2007; Yuvac1, 2013) .

Ebeveynler çocukların yetiştirilmesinde, karakter oluşumunda, değerlerin kazanımında en etkili rol modellerdir. Çocuk, model alarak öğrenmelerini gerçekleştirdiği bu dönemde, aile içindeki bir bireyin kendisiyle özdeşimini sağlamaktadır. Dolayısıyla üyelerin kişiliklerinde bir bozukluk olması durumunda olumsuz davranış örneğinin çocuğa yansıma ihtimali artmaktadır. İlk öğrenmelerin aile ortamında sağlandığı düşünüldüğünde, ebeveynin olumlu rol model örneği olması ve çocuğunun olumlu ahlaki davranışlarını pekiştirmesi sağlıklı toplumsallaşma noktasında da önemlidir. Bütün değerlerin temelinde olan sevgi değeri öncelikle ailede karşılanır. Ailede bu sevgiden mahrum büyüyen çocuk, bütün ihtiyaçları karşılansa bile psikolojik açıdan tutarsız davranışlar sergileyecektir. Çocuğun sağlıklı aile ilişkilerinden yoksun kalması, onun duygusal ve zihinsel gelişimini olumsuz biçimde etkileyebilmektedir. Doğru veya etkin bir şekilde değer kazanımı sağlanamadığında ileri dönemlerde bu, mutsuzluk ve uyumsuzluk kaynağı olabilmektedir. Sosyal kontrol aracı olarak şiddetin görüldüğü ya da gösterildiği ailelerde büyüyen çocukların ileriki dönemlerde şiddete eğilimleri de daha fazla olacaktır. Değer eğitimi ile olumlu iletişim becerileri kazanamayan bireylerin problemlerini konuşarak değil şiddete başvurarak çözmesi kaçınılmaz olacaktır. Annesiz babasız büyümek, dağılmış ailede büyümek, kavganın çatışmanın olduğu ortamda büyümek, aile dengesini bozacak anne ya da baba örneğini gözlemleyerek büyümek çocuğun ruhsal yapısını etkilemek- 
te ve çocukta derin izler bırakmaktadır. Ailenin dezavantajlı fonksiyonlarından dolayı her çocuk öz aile ortamında büyüme şansına sahip değildir. Korunmaya muhtaç çocuklar, 2828 sayılı Sosyal Hizmetler Kanunu ve 5395 sayılı Çocuk Koruma Kanunu çerçevesinde ilgili mahkeme tarafından haklarında korunma kararı/bakım tedbiri alınan çocuklardır. Beden, ruh, ahlak gelişimleri tehlikede olup; ana ve/ veya babasız, ana ve/veya babası belli olmayan, ana ve/ veya babası tarafindan terk edilen, ana veya babası tarafindan ihmal edilip fuhuş, dilencilik, alkollü içkileri veya uyuşturucu maddeleri kullanma gibi her türlü sosyal tehlikelere ve kötü alışkanlıklara karşı savunmasız bırakılan ve başıboşluğa sürüklenen çocuklardır (Aydın ve Gürler, 2014; Beil, 1996; Erkan, 1995; İşkol Fidan, 2005; Kutlu, 1992; Sosyal Hizmetler Kanunu, 1983; Yalçın, 2010 ve Yörükoğlu, 2007).

Korunmaya ihtiyacı olan çocukların reşit oluncaya kadar bu kanun hükümlerine göre kurumca kurulan sosyal hizmet kuruluşlarında bakılıp yetiştirilmeleri ve bir meslek sahibi edilmeleri hususundaki gerekli tedbir kararı 3/7/2005 tarihli ve 5395 sayılı Çocuk Koruma Kanununa göre yetkili ve görevli mahkemece alınmaktadır. Bu karar için gerekli belgeler kurumca düzenlenip ilgili mahkemeye gönderilmektedir. Haklarında derhal korunma tedbiri alınmasında zorunluluk görülen çocuklar mahkeme kararı alınıncaya kadar, bu kanuna göre kurulmuş kuruluşlarda veya aile yanında mahalli mülki amirin onayı alınmak suretiyle bakım altına alınmaktadır. Sosyal hizmet kuruluşlarının kendisine teslim edilen çocuk hakkında yapacağı inceleme sonucunda hazırlayacağı raporda, 5395 sayılı Kanun'un 9 uncu maddesi uyarınca çocuğun derhâl korunma altına alınmasını gerektiren bir durum olmadığı ve ailesine teslim edilmesinde herhangi bir sakınca bulunmadığı kanaatine varması hâlinde mülki idare amirinin onayı ile çocuk ailesine teslim edilebilmektedir. Mahkemece korunma karar1 alınan korunmaya ihtiyacı olan çocuğun bakımı ve yetiştirilmesi bu kanuna göre kurulmuş kuruluşlarda olduğu kadar kurumun denetim ve gözetiminde bir koruyucu aile tarafindan da yerine getirilebilmektedir. Korunma kararı genel olarak çocuk reşit olana kadar devam etmektedir. Ancak bu karar korunma kararına neden olan şartların ortadan kalkması halinde kurum yetkililerinin önerisi üzerine mahkemece çocuk reşit olmadan önce kaldırılabileceği gibi reşit olduktan sonra da çocuğun rızası alınmak şartıyla devamı hususunda karar verilebilmektedir (Sosyal Hizmetler Kanunu, 1983).

Korunmaya muhtaç çocuklara verilen hizmetlerden en eski ve en yaygın olanı "kışla bakım modeli" olarak da adlandırılan kuruluş bakım hizmetidir. Bu hiz- 
met modelinde 0-18 yaş arası korunmaya muhtaç çocukların korunma, bakılma, bir iş veya meslek sahibi edilme ve topluma yararlı kişiler olarak yetişmeleri büyük gruplar halinde sağlanmaktadır. Sonrasında kurumlar koğuş tipinden oda sistemine ve daha az çocuğun barındığ 1 sistemlere dönüşmeye başlamıştır. Çocuk evleri siteleri ve çocuk evleri bakım modelleri ile korunma altına alınan çocukların toplumsallaşma süreci desteklenmektedir. Çocuk evleri sitesi, korunma ihtiyacı olan çocukların aynı yerleşkede bulunan birden fazla küçük müstakil binalardan oluşturulan site içinde bakımının sağlandığı, ev tipi sosyal hizmet biriminden oluşan kuruluştur. Çocuk evleri ise 0-18 yaşlar arasındaki korunmaya ihtiyacı olan çocukların kaldığı ev birimleridir. Her ilin sosyal, kültürel açıdan çocuk yetiştirmeye uygun bölgelerinde tercihen il merkezinde okul ve hastanelere yakın apartman dairesi veya müstakil dairelerde 5 ila 8 çocuğun kaldığ1 evlerdir (Kutlu, 1992; İşkol Fidan, 2005; Saçan, 2010; Sosyal Hizmetler Kanunu, 1983) .

Korunmaya ihtiyacı olan çocukların Türk örf, adet, inanç ve milli ahlakına sahip, kendisine güvenen, insan sevgi ve saygısıyla dolu, Atatürkçü düşünce ve Atatürk ilke ve inkılâplarına uygun olarak yetiştirilmeleri, bir iş veya meslek sahibi yapılmaları, koruma kararı kalktıktan sonra da toplum içinde izlenmeleri ve imkânlar ölçüsünde desteklenmeleri hedeflenmektedir. Çocuk evi sistemi ile çocukların, diğer kurum bakım yöntemlerine nazaran daha toplum ile iç içe olmaları sağlanmaktadır. Kışla tipi kurum bakımında büyüyen yetişkinlerin birçoğunun sorumluluk vs. davranışlar konusunda desteklenemediği; çocuk evi sisteminde çocuklar ile bireysel ilgilenilerek sorumluluk, paylaşma, özgüven, yardımlaşma, nezaket, saygılı olma davranışlarını daha kalıcı hale getirmek için uygun ortamlar sağlanmaktadır. Kurumların, koğuş tipinden oda sistemine ve daha az çocuğun barındığı sistemlere dönüştürülmesi ile kurulan ilişkilerin sıcak olması sağlamaktadır. Komşuluk ilişkileri, alışveriş alışkanlıkları kazandırılmakta ve çocuk evini kendi evi gibi benimseyerek huzurlu bir ortamda yetiştirilmektedirler. Çocukların toplumla iç içe olmasından dolayı toplumsal normları ögrenip onlara uygun yaşaması konusunda daha aktif desteklenebilmektedirler. Çocuk evlerinde 5 ila 8 çocuk kalmaktadır ve bu çocuklar ile beraber üç bakım elemanı düzenli olarak kalmaktadır. Bakım elemanları nöbet sistemiyle çalışmaktadır ve bu bakım elemanlarının mümkün oldukça değişmemesi sağlanmaktadır. Çocuklar ile ilgilenen bakım elemanlarının kalıcılığının sağlanması ile çocuklarda güven duygusu, bağlanma duygusu desteklenmektedir. Çocuklarla ilgilenen personellerle kurulan güven ilişkisi ile psikososyal ve ruhsal gelişimleri olumlu etkilenmektedir. Bakım elemanlarının göreve başla- 
madan önce ve sonrasında aldıkları hizmet içi eğitimler ile de çocuk gelişimi ve çocuklarla iletişim konularında desteklenmektedirler. Evlerde kalan çocuk sayısının az olmasının sonucu çocuklar ile daha fazla bireysel ilgilenilerek kişisel farklılıklarına uygun şekilde olumlu davranışların kazandırılması mümkün hale gelmektedir. Ayrıca yaş ve cinsiyete bakılmadan kardeşlerin ayrılmayarak birlikte yaşamaları sağlanmaktadır. Bu kardeşlerin birbirine olan bağını güçlendirmektedir. Çocukların evde yaşayan diğer çocuklarla ortak paylaşımlarının aralarındaki bağı güçlendirmesi ve birbirlerini sahiplenip desteklemeleri beklenmektedir. Çocuğun yüksek yararı gözetilerek aile odaklı çalışmalar ile de çocukların izinli gidip gelmeleri, ziyaret edilmeleri sağlanmaktadır. Çocuk sayısının az olmasından dolayı ziyaret ve izin durumlarının çocuklar üzerindeki etkileri daha sağlıklı gözlemlenebilmektedir. Bu şekilde uygun olan durumların değerlendirilerek korunma kararı kaldırılarak aileye dönme odaklı çalışmaların daha sağlıklı olması gerçekleştirilmektedir (Akbulut, 2006; İnce, 2013; Nalbant, 2016; Yazıc1, 2012).

Korunmaya muhtaç çocuklar için bu şartlarda sağlıklı aile ortamına benzer ortamlar düzenlenmesi ile kişilik gelişimleri üzerinde pozitif etkilerin oluşmas1 beklenmektedir. Bu nedenle bu çalışmada çocuk evlerinde kalan korunmaya muhtaç okul öncesi dönem çocuklarının ahlaki değer yapılarının, kurumda kalma süresi, korunma altına alınma nedeni, kardeşleri ile birlikte/ ayrı olma, izne gitme durumları ve ziyaret edilme durumlarından etkilenip etkilenmediği araştırılmıştır. $\mathrm{Bu}$ araştırma ile çocuk evlerinde sağlanan koşulların çocukları ne yönde etkilediği ve bu sonuçlar doğrultusunda koşulların geliştirmesi için literatür destekli tartışma yapılmış ve öneriler sunulmuştur. Yapılan literatür taramasında korunmaya muhtaç çocuklar ile ilgili olan araştırmaların çoğunda büyük yaş grubuyla çalışmaların yoğunlukta olduğu görülmektedir (Berens ve Nelson, 2015; Cebe, 2005; Gibbons, 2007; Güçray, 1989; Gürvardar, 2001; Kaler ve Freeman, 1994; Şenocak, 2005; Turan, 2003; Yalçın, 2011; Yazıcı, 2013). Yapılan araştırmaların aksine bu araştırmada korunmaya muhtaç çocukların ahlaki değer yapıları incelenmesinde küçük yaş grubu 61-72 aylık çocuklar ile çalışılmıştır. Ayrıca çocuk evlerinin çoğunlukla açıldığı il Ankara'dır ve bu çalışma 61-72 aylık çocukların ahlaki değer yapılarının incelenmesi konusunda Ankara örnekleminde gerçekleştirilen ilk çalışmadır. 


\section{Yöntem}

Araştırmada genel tarama modellerinden ilişkisel tarama modeli kullanılmıştır. Değişkenler arasındaki ilişkinin tanımlanması nedeniyle korelasyonel araştırmalar, betimsel araştırmaların bir türü olarak nitelenirler. Korelasyonel olarak da adlandırılan ilişsisel tarama modellerinde iki ya da daha fazla değişkenin birlikte değişimi incelenmektedir (Büyüköztürk, Çakmak, Akgün, Karadeniz ve Demirel, 2010). Bu araştırmada korunmaya muhtaç çocukların ahlaki değer yapıları ile kurumda kalma süresi, korunma altına alınma nedeni, aile yanına izinli gitme durumu, ziyaret edilme durumları ve kardeşleriyle birlikte /ayrı olma durumu değişkenleri arasındaki ilişki incelenmiştir.

\section{Çalışma Grubu}

Araştırmanın çalışma grubunu Ankara ilinde çocuk evlerinde kalmakta olan 6172 aylık kız $(\mathrm{N}=29)$ ve erkek $(\mathrm{N}=19)$ korunmaya muhtaç çocukların tamamı oluşturmaktadır $(\mathrm{N}=48)$. Araştırmada veri toplama aracını korunmaya muhtaç çocuklar ile ilgilenen bakım elemanları doldurmuştur.

\section{Veri Toplama Araçları}

Kişisel Bilgi Formu: Çocuk evlerinde kalan çocuklar için hazırlanan kişisel bilgi formunda korunma altına alınma nedenlerine, kurumda kalma sürelerine, aile yanına izinli gitme durumuna, yakınları tarafindan ziyaret edilme durumuna ve kardeşleriyle birlikte/ayrı olma durumuna yönelik bilgiler yer almaktadır.

Ahlaki Değer Yapısını Belirleme Ölçeği: Okul öncesi dönem çocuklarının ahlaki değer yapılarını belirlemek amacıyla Öztürk (2011) tarafından geliştirilen “Ahlaki Değer Yapısını Belirleme Ölçeği” kullanılmıştır. Ölçeğin geliştirilme sürecinde alan yazın doğrultusunda öncelikle sekiz alt boyut belirlenmiş ve her bir alt boyut için maddeler oluşturularak toplam 110 maddeden oluşan madde havuzu için uzman görüşüne başvurulmuştur. Kapsam geçerliği çalışmasında beş akademisyen ve iki okul öncesi öğretmeni olmak üzere yedi uzmanın görüşlerine başvurulmuştur. Maddeler 5'li likert tipinde derecelendirilmiştir. Uzman değerlendirmesi sonucunda yapılan düzenleme ile 3lü likert tipinde derecelendirilmiştir. Sonrasında ölçek öğretmenlerin çocuklar üzerindeki son üç aylık gözlemlerine dayalı olarak öğretmenler tarafından ön uygulama kapsamında 60; toplamda ise 553 çocuk için doldurulmuştur. Elde edilen veriler 
doğrultusunda cronbach alfa güvenirlik katsayısı hesaplanmıştır. Hesaplanan katsayı adalet için 0,915; sorumluluk için 0,917; nezaket için 0,901; yardımseverlik için 0,922; özgüven için 0,929; liderlik için 0,923; saygl için 0,913; sabır için 0,881 olarak hesaplanmıştır. Ölçekte yer alan tüm maddelerin güvenirlik katsayısı 0,985 olarak belirlenmiştir. Güvenirlik kapsamında ayrıca test-tekrar test yöntemine başvurulmuştur. Adalet alt boyutu için 0,833, sorumluluk alt boyutu için 0,987, nezaket alt boyutu için 0,937, yardımseverlik alt boyutu için 0,999, özgüven alt boyutu için 0,997, liderlik alt boyutu için 0,991, sayg $\iota$ alt boyutu için 0,978 , sabır alt boyutu için test-tekrar test korelasyon katsayısının 0,922 olduğu tespit edilmiştir.

Boyutlar arasında korelasyon katsayısı hesaplanmış ve adalet değer yapıs1nın diğer alt boyutlarla anlamlı bir ilişki göstermediği belirlenmiştir ( $>0,05)$. Diğer boyutlar arasında ise pozitif yönde ve yüksek düzeyde ilişkiler olduğu saptanmıştır ( $\mathrm{p}<0,01)$ (Öztürk, 2011).

$\mathrm{Bu}$ araştırma kapsamında korunmaya muhtaç olup çocuk evlerinde kalmakta olan 48 çocuğun ahlaki değer yapısı incelenmiştir. Çocuklar ile ilgili verilen cevaplar doğrultusunda hesaplanan iç tutarlılık cronbach alfa güvenirlik katsayısı sonuçları "Ahlaki Değer Yapısı Belirleme Ölçeği” toplamına bakıldığında çocuk evlerinde kalan çocuklar için 0.979'dur. Bu değerler incelendiğinde çocuk evlerinde kalan çocukların verilerinin, "Ahlaki Değer Yapısı Belirleme Ölçeği” alt boyutları ve ölçeğin tamamı için yüksek derecede güvenilir olduğu sonucuna ulaşılmaktadır.

\section{Verilerin Toplanması ve Çözümlenmesi}

Aile ve Sosyal Politikalar Bakanlığı ilgili birimleri ile yapılan yazışmalar neticesinde çocuk evlerinde uygulama yapma izni alındıktan sonra Ankara Aile ve Sosyal Politikalar Bakanlığı İl Müdürlüğüne bağlı olan Ankara Çocuk Evleri Koordinasyon Merkezi eğitim birimi ile görüşmeler yapılmış ve çocuk evlerinde kalan 61-72 aylık çocukların sayısı öğrenilmiştir. Çocuk evlerinin grup sorumluları ile görüşülmüş ve çocuklar ile ilgili ölçekleri dolduracak bakım elemanlarının bu çocuklarla birlikte en az 3 ay çalışıp gözlem yapmış, çocuklar hakkında bilgi sahibi elemanlar olmalarına dikkat edilmiştir.

Çocuk evlerinin adresleri alınarak evler yaklaşık iki hafta süresince ziyaret edilmiş ve bakım elemanları ölçekler hakkında bilgilendirilerek anketler teslim 
edilmiştir. Objektif doldurmalarının çalışma bakımından önemine vurgu yapılmıştır. Ölçeklerin doldurulma aşamasında eşlik edilerek herhangi bir soru ya da yanlış anlaşılma durumunda rehberlik sağlanmıştır. Ölçekler evler ziyaret edilerek doldurulduğu için araştırma kapsamında 61-72 aylık çocukların tamamına ulaşılmıştır.

Verilerin analizinde; çocuk evlerinde kalan çocukların demografik ve kurum bakımı ile ilgili özelliklerine göre kategorilerde yer alan çocuk sayısının 30'un altında olması ve kategorilerdeki çocuk sayıları arasındaki farkların yüksek olması dolayısıyla karşılaştırmalarda non-parametrik istatistiksel işlemler kullanılmıştır. Çocukların “Ahlaki Değer Yapısı Belirleme Ölçeği”nden aldıkları puanların:

- Cinsiyetlerine, aileleri yanına izinli gitme durumlarına, aileleri tarafindan ziyaret edilme durumlarına ve kardeşleriyle ayrı/birlikte olma durumlarına göre karşılaştırılmasında Mann Whitney U testi kullanılmıştır.

- Kardeş sayılarına, kurumda kalma nedenine ve kurumda kalma süresine göre karşılaştırılmasında Kruskal Wallis testi kullanılmıştır.

\section{Bulgular}

Bu bölümde korunmaya muhtaç çocukların ahlaki değer yapılarının kurumda kalma süreleri, korunma altına alınma nedenleri, izinli gitme durumları, ziyaret edilme durumları ve kardeşleriyle birlikte ayrı olma durumlarına göre incelenmesine ilişkin bulgulara yer verilmiştir.

\section{1) Kurumda Kalma Süresi/ Ahlaki Değer Yapısını Belirleme Ölçeği}

\begin{tabular}{|c|c|c|c|c|c|c|c|}
\hline Ölçek boyutları & $\begin{array}{l}\text { Kurumda kalma } \\
\text { süresi }\end{array}$ & $\mathrm{N}$ & $\overline{\mathrm{x}} \pm \mathrm{SS}$ & Sira $\bar{x}$ & $\mathrm{Df}$ & $\mathrm{X}^{2}$ & $\mathrm{P}$ \\
\hline \multirow{3}{*}{ Adalet } & 1 yil ve alt1 & 14 & $25,71 \pm 4,98$ & 15,68 & \multirow{3}{*}{2} & \multirow{3}{*}{8,839} & \multirow{3}{*}{$0,012^{*}$} \\
\hline & $2 \mathrm{y} 1 \mathrm{l}$ & 18 & $29,72 \pm 7,51$ & 25,94 & & & \\
\hline & 3 yıl ve üzeri & 16 & $32,31 \pm 3,59$ & 30,59 & & & \\
\hline \multirow{3}{*}{ Sorumluluk } & 1 yil ve altı & 14 & $32,00 \pm 6,42$ & 13,25 & \multirow{3}{*}{2} & \multirow{3}{*}{13,485} & \multirow{3}{*}{$0,001^{*}$} \\
\hline & $2 \mathrm{y} 1 \mathrm{l}$ & 18 & $38,39 \pm 6,63$ & 27,39 & & & \\
\hline & 3 yıl ve üzeri & 16 & $40,56 \pm 4,21$ & 31,09 & & & \\
\hline \multirow{3}{*}{ Nezaket } & 1 yıl ve altı & 14 & $24,79 \pm 3,72$ & 15,18 & \multirow{3}{*}{2} & \multirow{3}{*}{9,723} & \multirow{3}{*}{$0,008^{*}$} \\
\hline & $2 \mathrm{y} 1 \mathrm{l}$ & 18 & $28,61 \pm 5,00$ & 26,22 & & & \\
\hline & 3 yıl ve üzeri & 16 & $30,31 \pm 4,64$ & 30,72 & & & \\
\hline
\end{tabular}


Okul Öncesi Dönemdeki Korunmaya Muhtaç Çocuklarnn Ahlâki Değer Yapılarnmn...

\begin{tabular}{|c|c|c|c|c|c|c|c|}
\hline \multirow{3}{*}{ Yardımseverlik } & 1 y1l ve altı & 14 & $31,14 \pm 4,47$ & 15,79 & \multirow{3}{*}{2} & \multirow{3}{*}{8,072} & \multirow{3}{*}{$0,018^{*}$} \\
\hline & $2 \mathrm{y} 11$ & 18 & $34,94 \pm 6,57$ & 26,81 & & & \\
\hline & 3 yil ve üzeri & 16 & $36,88 \pm 3,24$ & 29,53 & & & \\
\hline \multirow{3}{*}{ Özgüven } & 1 y1l ve alt1 & 14 & $34,64 \pm 5,31$ & 22,93 & \multirow{3}{*}{2} & \multirow{3}{*}{1,305} & \multirow{3}{*}{0,521} \\
\hline & 2 y1l & 18 & $34,06 \pm 7,82$ & 22,83 & & & \\
\hline & 3 yıl ve üzeri & 16 & $36,75 \pm 2,91$ & 27,75 & & & \\
\hline \multirow{3}{*}{ Liderlik } & $1 \mathrm{y} 1 \mathrm{l}$ ve altı & 14 & $34,00 \pm 5,96$ & 23,46 & \multirow{3}{*}{2} & \multirow{3}{*}{4,209} & \multirow{3}{*}{0,122} \\
\hline & $2 \mathrm{y} 11$ & 18 & $32,06 \pm 6,49$ & 20,36 & & & \\
\hline & 3 y1l ve üzeri & 16 & $37,06 \pm 5,41$ & 30,06 & & & \\
\hline \multirow{3}{*}{ Saygl } & 1 y1l ve altı & 14 & $25,93 \pm 2,79$ & 13,75 & \multirow{3}{*}{2} & \multirow{3}{*}{12,361} & \multirow{3}{*}{$0,002 *$} \\
\hline & $2 \mathrm{y} 1 \mathrm{l}$ & 18 & $31,33 \pm 6,66$ & 27,14 & & & \\
\hline & 3 yıl ve üzeri & 16 & $33,31 \pm 4,22$ & 30,94 & & & \\
\hline \multirow{3}{*}{ Sabur } & 1 y1l ve alt1 & 14 & $26,79 \pm 3,81$ & 16,96 & \multirow{3}{*}{2} & \multirow{3}{*}{6,690} & \multirow{3}{*}{$0,035^{*}$} \\
\hline & $2 \mathrm{y} 11$ & 18 & $30,94 \pm 5,87$ & 29,72 & & & \\
\hline & 3 yil ve üzeri & 16 & $30,13 \pm 4,65$ & 25,22 & & & \\
\hline \multirow{3}{*}{$\begin{array}{l}\text { Ahlaki Değer } \\
\text { Yapısı Belirleme } \\
\text { Ölçeği Toplam }\end{array}$} & 1 yil ve altı & 14 & $235,00 \pm 28,98$ & 15,39 & \multirow{3}{*}{2} & \multirow{3}{*}{10,168} & \multirow{3}{*}{$0,006^{*}$} \\
\hline & 2 y1l & 18 & $260,06 \pm 44,95$ & 25,22 & & & \\
\hline & 3 yil ve üzeri & 16 & $277,31 \pm 26,05$ & 31,66 & & & \\
\hline
\end{tabular}
$\mathrm{n}=48$

$p<0,05^{*}$

Tablo 1 incelendiğinde çocuk evlerinde kalan çocukların adalet, sorumluluk, nezaket, yardımseverlik, sayg alt boyutlarından ve ölçek toplamından aldıkları puanların "kurumda 3 yıl ve üzeri kalan çocuklar" lehine anlamlı bir farklılık gösterdiği görülmektedir $(\mathrm{P}<0.05)$. Çocukların sabır değer yapıları "kurumda 2 yıl kalan çocuklar" lehine anlamlı bir farklılık göstermektedir $(\mathrm{p}<0,05)$. Çocukların özgüven ve liderlik değer yapıları çocukların "kurumda kalma süreleri”ne göre anlamlı bir farklılık göstermemektedir $(\mathrm{p}>0,05)$.

\section{2) Korunma Altına Alınma Nedeni/ Ahlaki Değer Yapısını Belir- leme Ölçeği}

Tablo 2: Çocukların Korunma Altına Alınma Nedenine Göre “Ahlaki Değer Yapıları” na İlişkin Kruskal Wallis Testi

\begin{tabular}{|c|c|c|c|c|c|c|c|}
\hline Ölçek boyutları & $\begin{array}{l}\text { Korunma altına } \\
\text { alınma nedeni }\end{array}$ & $\mathrm{N}$ & $\overline{\mathrm{x}} \pm \mathrm{SS}$ & Sira $\bar{x}$ & df & $\mathrm{X}^{2}$ & $\mathrm{P}$ \\
\hline \multirow{4}{*}{ Adalet } & 1 & 13 & $28,08 \pm 6,29$ & 20,88 & \multirow{4}{*}{3} & \multirow{4}{*}{3,482} & \multirow{4}{*}{0,323} \\
\hline & 2 & 17 & $30,71 \pm 6,47$ & 27,53 & & & \\
\hline & 3 & 7 & $31,57 \pm 4,61$ & 29,79 & & & \\
\hline & 4 & 11 & $27,64 \pm 6,42$ & 20,73 & & & \\
\hline \multirow{4}{*}{ Sorumluluk } & 1 & 13 & $36,38 \pm 5,88$ & 21,77 & \multirow{4}{*}{3} & \multirow{4}{*}{3,547} & \multirow{4}{*}{0,315} \\
\hline & 2 & 17 & $38,82 \pm 7,58$ & 29,29 & & & \\
\hline & 3 & 7 & $37,57 \pm 5,59$ & 24,64 & & & \\
\hline & 4 & 7 & $35,64 \pm 7,28$ & 20,23 & & & \\
\hline
\end{tabular}




\begin{tabular}{|c|c|c|c|c|c|c|c|}
\hline \multirow{4}{*}{ Nezaket } & 1 & 13 & $27,38 \pm 5,95$ & 21,85 & \multirow{4}{*}{3} & \multirow{4}{*}{1,547} & \multirow{4}{*}{0,672} \\
\hline & 2 & 17 & $29,00 \pm 5,24$ & 27,76 & & & \\
\hline & 3 & 7 & $27,86 \pm 3,24$ & 23,86 & & & \\
\hline & 4 & 7 & $27,55 \pm 4,61$ & 23,00 & & & \\
\hline \multirow{4}{*}{ Yardımseverlik } & 1 & 13 & $34,23 \pm 5,59$ & 23,46 & \multirow{4}{*}{3} & \multirow{4}{*}{3,313} & \multirow{4}{*}{0,346} \\
\hline & 2 & 17 & $35,41 \pm 6,12$ & 28,03 & & & \\
\hline & 3 & 7 & $35,71 \pm 4,68$ & 27,00 & & & \\
\hline & 4 & 7 & $32,55 \pm 4,78$ & 18,68 & & & \\
\hline \multirow{4}{*}{ Özgüven } & 1 & 13 & $33,38 \pm 7,11$ & 21,85 & \multirow{4}{*}{3} & \multirow{4}{*}{1,171} & \multirow{4}{*}{0,760} \\
\hline & 2 & 17 & $35,47 \pm 4,94$ & 24,88 & & & \\
\hline & 3 & 7 & $37,14 \pm 6,09$ & 28,86 & & & \\
\hline & 4 & 7 & $35,36 \pm 5,55$ & 24,27 & & & \\
\hline \multirow{4}{*}{ Liderlik } & 1 & 13 & $33,46 \pm 9,73$ & 24,92 & \multirow{4}{*}{3} & \multirow{4}{*}{0,976} & \multirow{4}{*}{0,807} \\
\hline & 2 & 17 & $35,29 \pm 4,63$ & 26,53 & & & \\
\hline & 3 & 7 & $34,71 \pm 3,73$ & 23,86 & & & \\
\hline & 4 & 7 & $33,45 \pm 4,82$ & 21,27 & & & \\
\hline \multirow{4}{*}{ Saygl } & 1 & 13 & $29,08 \pm 6,41$ & 21,88 & \multirow{4}{*}{3} & \multirow{4}{*}{1,900} & \multirow{4}{*}{0,593} \\
\hline & 2 & 17 & $32,06 \pm 5,84$ & 28,21 & & & \\
\hline & 3 & 7 & $29,86 \pm 5,30$ & 23,14 & & & \\
\hline & 4 & 7 & $29,82 \pm 5,21$ & 22,73 & & & \\
\hline \multirow{4}{*}{ Sabır } & 1 & 13 & $30,15 \pm 5,90$ & 26,88 & \multirow{4}{*}{3} & \multirow{4}{*}{1,329} & \multirow{4}{*}{0,722} \\
\hline & 2 & 17 & $28,88 \pm 4,99$ & 23,47 & & & \\
\hline & 3 & 7 & $27,43 \pm 4,65$ & 20,07 & & & \\
\hline & 4 & 7 & $30,82 \pm 4,87$ & 26,09 & & & \\
\hline \multirow{5}{*}{$\begin{array}{l}\text { Ahlaki Değer Yapısı } \\
\text { Belirleme Ölçeği } \\
\text { Toplam }\end{array}$} & 1 & 13 & $252,15 \pm 45,81$ & 22,50 & \multirow{4}{*}{3} & \multirow{4}{*}{1,886} & \multirow{4}{*}{0,596} \\
\hline & 2 & 17 & $265,65 \pm 39,04$ & 27,68 & & & \\
\hline & 3 & 7 & $261,86 \pm 32,06$ & 25,93 & & & \\
\hline & 4 & 7 & $252,82 \pm 33,63$ & 21,05 & & & \\
\hline & & $\mathrm{n}=$ & & & & & \\
\hline
\end{tabular}

1-Anne ve/veya babanın terk etmesi 2- Anne ve babanın boşanması 3- Anne ve/veya babanın sağlık durumu 4- İhmal-istismar-ekonomik yetersizlikler

Tablo 2 incelendiğinde çocuk evlerinde kalan çocukların "korunma altına alınma nedenleri” ne göre adalet, sorumluluk, nezaket, yardımseverlik, özgüven, liderlik, saygl, sabır ve ahlaki değer toplam puanlarının anlamlı bir farklıl1k göstermediği görülmektedir ( $\mathrm{p}>0.05$ ).

\section{3) Aile Yanına İzinli Gitme Durumu/ Ahlaki Değer Yapısını Belirleme Ölçeği}

Tablo 3: Çocukların Aile Yanına İzinli Gidip Gitmeme Durumuna Göre “Ahlaki Değer Yapıları”na İlişkin Mann Whitney U Testi

\begin{tabular}{lccccccc}
\hline $\begin{array}{l}\text { Ölçek boyut- } \\
\text { ları }\end{array}$ & $\begin{array}{c}\text { Ailesinin yanına } \\
\text { izinli gitme durumu }\end{array}$ & $\mathrm{N}$ & $\overline{\mathrm{x}} \pm \mathrm{SS}$ & $\begin{array}{c}\text { Sira } \\
\text { Ortalamas }\end{array}$ & Sira Toplamı & $\mathrm{Z}$ & $\mathrm{p}$ \\
\cline { 2 - 6 } Adalet & Gidiyor & 26 & $30,19 \pm 4,99$ & 26,04 & 677,00 & & \\
\cline { 2 - 6 } & Gitmiyor & 22 & $28,50 \pm 7,39$ & 22,68 & 499,00 & 0,830 & 0,406 \\
\hline
\end{tabular}


Okul Öncesi Dönemdeki Korunmaya Muhtaç Çocuklarnn Ahlâki Değer Yapılarnnn...

\begin{tabular}{|c|c|c|c|c|c|c|c|}
\hline \multirow{2}{*}{ Sorumluluk } & Gidiyor & 26 & $37,31 \pm 6,39$ & 24,15 & 628,00 & \multirow{2}{*}{0,187} & \multirow{2}{*}{0,852} \\
\hline & Gitmiyor & 22 & $37,18 \pm 7,27$ & 24,91 & 548,00 & & \\
\hline \multirow{2}{*}{ Nezaket } & Gidiyor & 26 & $27,62 \pm 4,58$ & 23,15 & 602,00 & \multirow{2}{*}{0,727} & \multirow{2}{*}{0,467} \\
\hline & Gitmiyor & 22 & $28,59 \pm 5,47$ & 26,09 & 574,00 & & \\
\hline \multirow{2}{*}{ Yardımseverlik } & Gidiyor & 26 & $34,81 \pm 4,87$ & 25,06 & 651,50 & \multirow{2}{*}{0,302} & \multirow{2}{*}{0,763} \\
\hline & Gitmiyor & 22 & $34,09 \pm 6,18$ & 23,84 & 524,50 & & \\
\hline \multirow{2}{*}{ Özgüven } & Gidiyor & 26 & $34,65 \pm 5,04$ & 22,96 & 597,00 & \multirow{2}{*}{0,831} & \multirow{2}{*}{0,406} \\
\hline & Gitmiyor & 22 & $35,68 \pm 6,74$ & 26,32 & 579,00 & & \\
\hline \multirow{2}{*}{ Liderlik } & Gidiyor & 26 & $34,77 \pm 5,17$ & 24,90 & 647,50 & \multirow{2}{*}{0,218} & \multirow{2}{*}{0,827} \\
\hline & Gitmiyor & 22 & $33,73 \pm 7,40$ & 24,02 & 528,50 & & \\
\hline \multirow{2}{*}{ Saygl } & Gidiyor & 26 & $30,54 \pm 5,19$ & 24,21 & 629,50 & \multirow{2}{*}{0,156} & \multirow{2}{*}{0,876} \\
\hline & Gitmiyor & 22 & $30,27 \pm 6,47$ & 24,84 & 546,50 & & \\
\hline \multirow{2}{*}{ Sabir } & Gidiyor & 26 & $28,58 \pm 4,80$ & 21,83 & 567,50 & \multirow{2}{*}{1,448} & \multirow{2}{*}{0,148} \\
\hline & Gitmiyor & 22 & $30,50 \pm 5,45$ & 27,66 & 608,50 & & \\
\hline \multirow{2}{*}{$\begin{array}{l}\text { Ahlaki Değer } \\
\text { Yapısı Belir- } \\
\text { leme Ölçeği } \\
\text { Toplam }\end{array}$} & Gidiyor & 26 & $258,46 \pm 30,74$ & 24,10 & 626,50 & \multirow{2}{*}{0,217} & \multirow{2}{*}{0,828} \\
\hline & Gitmiyor & 22 & $258,55 \pm 46,42$ & 24,98 & 549,50 & & \\
\hline
\end{tabular}

Tablo 3 incelendiğinde çocukların adalet, sorumluluk, nezaket, yardımseverlik, özgüven, liderlik, saygı, sabır ve ahlaki değer yapılarının çocukların "ailesinin yanına izinli gitme durumu" na göre anlamlı farklılık göstermediği görülmektedir $(\mathrm{p}>0,05)$.

\section{4) Yakınları Tarafindan Ziyaret Edilme Durumu/ Ahlaki Değer Yapısını Belirleme Ölçeği}

Tablo 4: Çocukların Yakınları Tarafindan Ziyaret Edilme Durumuna Göre “Ahlaki Değer Yapıları”na İlişsin Mann Whitney U Testi

\begin{tabular}{|c|c|c|c|c|c|c|c|}
\hline $\begin{array}{l}\text { Ölçek } \\
\text { boyutları }\end{array}$ & $\begin{array}{l}\text { Ailesinin ziya- } \\
\text { ret etme durumu }\end{array}$ & $\mathrm{N}$ & $\overline{\mathrm{x}} \pm \mathrm{SS}$ & Sira Ortalaması & $\begin{array}{l}\text { Sira } \\
\text { Toplamı }\end{array}$ & $\mathrm{Z}$ & $\mathrm{P}$ \\
\hline \multirow{2}{*}{ Adalet } & Var & 39 & $30,97 \pm 5,38$ & 27,91 & 1088,50 & \multirow{2}{*}{3,525} & \multirow{2}{*}{$0,000^{*}$} \\
\hline & Yok & 9 & $22,67 \pm 4,97$ & 9,72 & 87,50 & & \\
\hline \multirow{2}{*}{$\begin{array}{l}\text { Sorumlu- } \\
\text { luk }\end{array}$} & Var & 39 & $38,87 \pm 5,76$ & 27,68 & 1079,50 & \multirow{2}{*}{3,291} & \multirow{2}{*}{$0,001 *$} \\
\hline & Yok & 9 & $30,22 \pm 6,38$ & 10,72 & 96,50 & & \\
\hline \multirow{2}{*}{ Nezaket } & Var & 39 & $29,23 \pm 4,52$ & 27,82 & 1085,00 & \multirow{2}{*}{3,436} & \multirow{2}{*}{$0,000^{*}$} \\
\hline & Yok & 9 & $23,00 \pm 3,61$ & 10,11 & 91,00 & & \\
\hline \multirow{2}{*}{$\begin{array}{l}\text { Yardim- } \\
\text { severlik }\end{array}$} & Var & 39 & $35,77 \pm 4,53$ & 27,44 & 1070,00 & \multirow{2}{*}{3,042} & \multirow{2}{*}{$0,002 *$} \\
\hline & Yok & 9 & $28,89 \pm 5,88$ & 11,78 & 106,00 & & \\
\hline \multirow{2}{*}{ Özgüven } & Var & 39 & $36,21 \pm 5,26$ & 26,94 & 1050,50 & \multirow{2}{*}{2,521} & \multirow{2}{*}{$0,010^{*}$} \\
\hline & Yok & 9 & $30,44 \pm 6,19$ & 13,94 & 125,50 & & \\
\hline \multirow{2}{*}{ Liderlik } & Var & 39 & $35,46 \pm 5,38$ & 26,60 & 1037,50 & \multirow{2}{*}{2,175} & \multirow{2}{*}{$0,029 *$} \\
\hline & Yok & 9 & $29,22 \pm 7,46$ & 15,39 & 138,50 & & \\
\hline \multirow{2}{*}{ Saygl } & Var & 39 & $31,79 \pm 5,21$ & 27,60 & 1076,50 & \multirow{2}{*}{$-3,207$} & \multirow{2}{*}{$0,001 *$} \\
\hline & Yok & 9 & $24,44 \pm 3,97$ & 11,06 & 99,50 & & \\
\hline
\end{tabular}




\begin{tabular}{|c|c|c|c|c|c|c|c|}
\hline \multirow{2}{*}{ Sabir } & Var & 39 & $30,23 \pm 4,94$ & 26,18 & 1021,00 & \multirow{2}{*}{1,742} & \multirow{2}{*}{0,086} \\
\hline & Yok & 9 & $26,11 \pm 4,91$ & 17,22 & 155,00 & & \\
\hline \multirow{3}{*}{$\begin{array}{l}\text { Ahlaki } \\
\text { Değer } \\
\text { Yapıs1 } \\
\text { Belirleme } \\
\text { Ölçeği } \\
\text { Toplam } \\
\end{array}$} & Var & 39 & $268,54 \pm 31,88$ & 27,86 & 1086,50 & \multirow[b]{2}{*}{3,463} & \multirow[b]{2}{*}{$0,000^{*}$} \\
\hline & Yok & 9 & $215,00 \pm 34,08$ & 9,94 & 89,50 & & \\
\hline & & $\mathrm{n}=\mathrm{L}$ & & & & & \\
\hline
\end{tabular}

Tablo 4 incelendiğinde araştırmaya katılan çocukların "yakınları tarafından ziyaret edilme durumları"na göre adalet, sorumluluk, nezaket, yardimseverlik, özgüven, liderlik, saygı alt boyutları ve ölçek toplamından aldıkları puanlar arasında "yakınları tarafından ziyaret edilenler" lehine anlamlı bir farklılık olduğu görülmektedir $(\mathrm{p}<0,05)$.

\section{5) Kardeşleriyle Birlikte/Ayrı Olma Durumu/Ahlaki Değer Yapısı Belirleme Ölçeği}

Tablo 5: Çocukların Kardeşiyle Birlikte/Ayrı Olma Durumuna Göre “Ahlaki Değer Yapıları”na İlişkin Mann Whitney U Testi

\begin{tabular}{|c|c|c|c|c|c|c|c|}
\hline Ölçek boyutları & Kardeşler & $\mathrm{N}$ & $\overline{\mathrm{x}} \pm \mathrm{SS}$ & $\begin{array}{l}\text { Sira } \\
\text { Ortala- } \\
\text { mas1 }\end{array}$ & $\begin{array}{l}\text { Sira } \\
\text { Toplamı }\end{array}$ & $\mathrm{z}$ & $\mathrm{P}$ \\
\hline \multirow{2}{*}{ Adalet } & Birlikte & 23 & $27,30 \pm 6,63$ & 18,89 & 434,50 & \multirow{2}{*}{$-1,522$} & \multirow{2}{*}{0,128} \\
\hline & Ayr1 & 19 & $30,53 \pm 5,54$ & 24,66 & 468,50 & & \\
\hline \multirow{2}{*}{ Sorumluluk } & Birlikte & 23 & $34,91 \pm 7,67$ & 18,98 & 436,50 & \multirow{2}{*}{$-1,472$} & \multirow{2}{*}{0,141} \\
\hline & Ayrı & 19 & $38,68 \pm 5,34$ & 24,55 & 466,50 & & \\
\hline \multirow{2}{*}{ Nezaket } & Birlikte & 23 & $26,35 \pm 4,75$ & 18,54 & 426,50 & \multirow{2}{*}{$-1,726$} & \multirow{2}{*}{0,084} \\
\hline & Ayrı & 19 & $29,00 \pm 5,07$ & 25,08 & 476,50 & & \\
\hline \multirow{2}{*}{ Yardımseverlik } & Birlikte & 23 & $32,35 \pm 5,87$ & 17,76 & 408,50 & \multirow{2}{*}{$-2,189$} & \multirow{2}{*}{$0,029 *$} \\
\hline & Ayrı & 19 & $36,16 \pm 4,55$ & 26,03 & 494,50 & & \\
\hline \multirow{2}{*}{ Özgüven } & Birlikte & 23 & $33,35 \pm 5,18$ & 18,22 & 419,00 & \multirow{2}{*}{$-1,915$} & \multirow{2}{*}{0,055} \\
\hline & Ayrı & 19 & $36,68 \pm 6,65$ & 25,47 & 484,00 & & \\
\hline \multirow{2}{*}{ Liderlik } & Birlikte & 23 & $32,13 \pm 6,57$ & 18,30 & 421,00 & \multirow{2}{*}{$-1,866$} & \multirow{2}{*}{0,062} \\
\hline & Ayr1 & 19 & $35,68 \pm 5,63$ & 25,37 & 482,00 & & \\
\hline \multirow{2}{*}{ Saygl } & Birlikte & 23 & $28,65 \pm 5,79$ & 18,54 & 426,50 & \multirow{2}{*}{$-1,725$} & \multirow{2}{*}{0,085} \\
\hline & Ayrı & 19 & $31,58 \pm 5,59$ & 25,08 & 476,50 & & \\
\hline \multirow{2}{*}{ Sabur } & Birlikte & 23 & $27,26 \pm 3,92$ & 16,43 & 378,00 & \multirow{2}{*}{$-2,967$} & \multirow{2}{*}{$0,003 *$} \\
\hline & Ayrı & 19 & $31,89 \pm 5,18$ & 27,63 & 525,00 & & \\
\hline \multirow{2}{*}{$\begin{array}{l}\text { Ahlaki Değer Yapısı Be- } \\
\text { lirleme Ölçeği Toplam }\end{array}$} & Birlikte & 23 & $242,30 \pm 39,23$ & 18,13 & 417,00 & \multirow{2}{*}{1,961} & \multirow{2}{*}{0,051} \\
\hline & Ayr1 & 19 & $270,21 \pm 32,76$ & 25,58 & 486,00 & & \\
\hline & & $\mathrm{n}=$ & & & & & \\
\hline
\end{tabular}

$p<0,05^{*}$

Tablo 5 incelendiğinde çocukların "kardeşleriyle birlikte/ayrı olma durumları" na göre adalet, sorumluluk, nezaket, özgüven, liderlik, saygl ve ahlaki değer yapısı toplam puanlarının anlamlı bir farklılık göstermediği görülmekte- 
dir. Yardımseverlik ve sabır değer yapıları "kardeşlerinden ayrı olan çocuklar" lehine anlamlı bir farkl1l1k göstermektedir.

\section{Tartışma ve Öneriler}

Araştırmada korunmaya muhtaç çocukların ahlaki değer yapılarının kurum ile ilgili bazı özelliklere göre ilişkisi incelenmiştir. Bu bölümde ilgili literatür 1şığında araştırma bulguları tartışılmaya çalışılmıştır.

Tablo 1'e göre kurumda 3 yıl ve üzeri yıl kalan çocukların "Ahlaki Değer Yapısı Belirleme Ölçeği” nden aldıkları puanların anlamlı derece de yüksek olduğu görülmektedir. Korunmaya muhtaç çocuklarla yapılan araştırmalar incelendiğinde daha çok büyük yaş grupları ile ya da yetiştirme yurdunda kalan çocuklarla yapılmıştır (Cebe, 2005; Güçray, 1989; Kalayc1, 2007; Kemerkaya, 2012; Koşay, 2013; Yıldırım, 2005). Bu araştırmada ise kalabalık kışla tipi bakım değil çocuk evi hizmet modeli ele alınmaktadır. Ayrıca araştırma kapsamında 61-72 aylık çocuk grubu incelenmektedir. Araştırmada çocukların çocuk evinde kalma sürelerinin artması ile ahlaki değer yapılarının arttı̆̆ 1 sonucu, çocuk evi sisteminin olumlu yanını ortaya koymaktadır. Çocuklar ile bireysel ilgilenilmesi, ihtiyaç duydukları sevgi ve şefkatin verilebilmesi, sabit rol modelin olması ve bu sabit modelle güven duygusunun doyurulmas gibi etkenlerin, çocukların değer yapılarının desteklenmesinde önemli rol oynadığı düşünülmektedir.

Tablo 2'ye göre çocuk evlerinde kalan korunmaya muhtaç çocukların korunma altına alınma nedenlerine göre "Ahlaki Değer Yapısı Belirleme Ölçeği” nden aldıkları puanlar anlamlı bir farklılık göstermemektedir. Yapılan literatür araştırmasında daha büyük yaşlardaki korunmaya muhtaç çocukların korunma altına alınma nedeninin, çocukların sosyal beceri puanlarının düşük olması, okulda problem davranışları sergilemeleri, kendilerine bakış açılarının ve özsaygılarının olumsuz olması ve bunlara bağlı olarak davranış sorunları yaşamalarını etkilediği ortaya konmaktadır (Amato ve Keith, 1991; Koşay, 2013; Şimşek, Erol, Öztop, Özer Özcan, 2008; Uslu, 2011). Araştırmanın çalışma grubundaki 61-72 aylık çocukların çoğunun 2 yıl ve daha fazla kurumda kaldıkları görülmektedir. Dolayısıyla bu araştırmada çalışılan çocukların korunma altına alınma durumunda yaşlarının çok daha küçük olduğu ve gelişimlerini olumsuz etkileyebilecek ortamlarda çok kalmayarak kurum bakımına alındıkları görülmektedir. Bundan dolayı ahlaki değer yapılarının korunma altında alınma nedeninden etkilenmediği düşünülmektedir. 
Tablo 3'e göre çocukların ahlaki değer yapılarının ailesi yanına izinli gitme durumuna göre anlamlı farklılık göstermemektedir. Diğer taraftan Tablo 4'e göre çocukların; yakınları tarafından ziyaret edilme durumuna göre ziyaret edilenler lehine anlamlı bir farklılık bulunmaktadır. Ahlaki değer kavramlarının çocuklarda kazanılması ve kalıcılığının sağlanması bir süreci gerektirir. Korunmaya muhtaç çocuklar aileleri yanına kısa süreli izinli gittiklerinden dolay1 ailesi yanına izinli gitme durumunun ahlaki değer yapıları üzerinde etkili olmadığ 1 şeklinde yorumlanabilir. Araştırma sonucunda yakınları tarafından ziyaret edilmeyen çocukların bu durumdan olumsuz etkilendiği görülmektedir. Ulaşılan bu sonuç ile çocukların çocuk evinde kaldıkları süreçte aileleri tarafından ziyaret edilmeleri ve ailenin desteğini hissetmelerinin önemi ortaya konulmuştur. Nitekim bu konuda yapılan çalışmalarda da kurum bakımındaki çocukların yakınları tarafından ziyaret edilme durumlarının çocukları olumlu yönde etkilediği sonucuna ulaşmıştır (Tümkaya, 2005; Üstüner, Erol, Şimşek, 2005; Y1ldırım, 2005; Yurdakul, 2016).

Tablo 5'e göre yardımseverlik ve sabır alt boyutlarında kardeşinden ayrı olanların lehine anlamlı bir farklılık bulunmaktadır. Bu sonucun sebebi olarak aynı evde kalan çocukların bir süre sonra kendilerini kardeş gibi hissetmeleri ve öz kardeşine duyulan özlemin diğer çocuklara karş1 yardımseverliğini arttırdığ1 söylenebilir. Aynı şekilde kurum bakımında uygun şartlar sağlanamayıp kardeşinden ayrı kalan çocukların bu durumu bir süre sonra kabullenerek yaşamaya başlaması ancak ayrı kalma duygusunun ve özlemin, sabır değerlerinin daha yüksek çıkmasına sebep olduğu düşünülmektedir Yapılan literatür araştırmasında da kardeşlerinden ayrı kalan korunmaya muhtaç çocuklarda kardeş özleminin arttığı, kardeşiyle görüşenlerin ruhsal durumunun daha olumlu olduğu sonucuna ulaşılmıştır (Gümüş, 2014; İnce, 2013). Diğer alt boyutlarda anlamlı farklı1ık çıkmaması ise çocuk evlerinde kalan çocukların düzenli olarak kardeşleri ile görüştürülmelerinin olumlu etkisi olarak yorumlanabilir.

Bu sonuçlar ışığında aşağıdaki öneriler sunulabilir;

Ailesi tarafindan ziyaret edilen çocukların ahlaki değer yapıları ziyaretçisi olmayan çocuklara nazaran daha yüksek çıkmıştır. Çocukların ziyaretçisinin olması durumu ile yalnızlık duygusundan uzaklaşmaları sağlanıp, sevilme, sahiplenilme duygularının doyurulduğu düşünülmektedir. Bu doğrultuda ailelerin ve yakınlarının bilinçlendirilerek çocukların ziyaretçileri ile daha kaliteli bir şekilde görüştürülmesi sağlanmalıdır. Bu kapsamda görüşme saatlerinde ebeveyn çocuk etkileşimin daha nitelikli hale getirilmesi sağlanabilir. Buna firsat verecek 
aktiviteler planlanabilir. Velilerle çocukların birlikte vakit geçirebileceği bir film, konser ortamı oluşturulabilir ya da beraber oynayabilecekleri farklı oyunlar planlanabilir. Bu şekilde aktiviteler ile çocukların veli ziyaretlerinden daha olumlu yönde etkilenmesi sağlanabilir. Öz ailesi ile hiçbir iletişimi olmayan ve başka bir ziyaretçisi olmayan çocukların koruyucu aile gibi sistemlere yönlendirilerek aile ortamı ve sıcaklığına kavuşmaları sağlanmalıdır.

$\mathrm{Bu}$ araştırmada çocukların korunma altına alınmalarında çoğunlukla ebeveynlerin boşanmalarının ve çocukların terk edilmesinin neden olduğu görülmektedir. Bu noktada evlilik kurumunun oluşturulması, evlilik yaşamının devamını sağlayacak koşul ve imkânların yaratılmasına önem verilmelidir. Toplumsal bilinç arttırılmalı ve aile bütünlüğünün sağlanması için gerekli rehberlik ve destek çalışmaları gerçekleştirilmelidir. Aile refah hizmetlerine verilen önem ile ekonomik yetersizlikten doğabilecek sonuçlar en aza indirilmelidir.

Çocuk evlerinde kalan çocukların kardeşleri ile iletişiminin daha verimli ve olumlu olması için çalışmalar yapılmalıdır. Gidilen sosyal faaliyetlerde katılacak evler belirlenme aşamasında, kardeş evlerin ayarlaması yapılarak kardeşlerin mümkün olduğunca çok vakit geçirmelerinin sağlanması hedeflenmelidir. Aile görüşlerinde de farklı evlerde kalan kardeşler bir araya getirilmelidir. $\mathrm{Bu}$ şekilde aile bağlarının daha da kuvvetlendirilmesi için mesleki çalışmalar arttırılmalıdır. Meslek elemanlarına bu konuda verilen eğitimlerde bu konunun önemine de vurgu yapılmalıdır.

Çocuk evlerinde 3 yıl ve üzeri kalan çocukların ahlaki değer yapılarının bundan olumlu etkilendiği sonucu ile kışla tipi bakım modelinden ev tipi hizmet modeline geçmenin önemi araştırmada vurgulanmıştır. Bu doğrultuda Aile ve Sosyal Politikalar Bakanlı̆̆ kapsamında çalışmalar devam etmektedir. Yurtlarda kalan çocukların birçoğu ev tipi bakım hizmetlerine yönlendirilmektedir. Bu konuda çocuk evi sisteminin niteliği arttırılmalıdır. Çocuk evlerinin denetimini gerçekleştiren ev sorumlularının ev sayısının fazla olması ile çocukların her bir işlemini gerçekleştirme firsatı bulamaması sorununu ortaya çıkarabilir. Bu sebeple ev sayılarının ideal sayılara çekilmesi ile ilgili çalışmalar gerçekleştirilebilir. Bu şekilde ev sorumlularının çocukların bireysel sorunlarıyla da daha aktif ilgilenebilmesi sağlanabilecektir. Bunun yanı sıra bakım elemanları 24 saat nöbet sistemiyle çalışmaktadır. Bu durumda vardiyalı sistem gibi bir uygulama ile elemanların daha verimli çalışma saatleri geçirmeleri sağlanabilir.

Çocuk evi sisteminin çocukları destekleme konusunda yetersiz kaldığı noktalar saptanmalı, başka illerde ve başka kurumlarda da bu yaş grubu ile de ça- 
lışmalar arttırılmalı ve çocuk evi sisteminin olumlu yönde geliştirilmesi için gerekli düzenlemelerin yapılmasına destek olunmalıdır.

\section{Kaynakça}

Akbulut Ş. A. (2006). Korunmaya muhtaç çocuk kavramina yeni yaklaşım (topsullaşma sürecinde uygulanan sistemlerin analizi: İzmir örneği) (Doktora tezi). Ege Üniversitesi Sosyal Bilimler Enstitüsü, İzmir.

Amato, P. R. \& Keith, B. (1991). Parental divorce and adult well-being: A meta-analysis. Journal of Marriage and the Family, 1(53), 43-58.

Arabacı, B. \& Akgül, T. (2013). Elazığ ilinde uygulanan etkinlik temelli değer öğretimi uygulamalarının değer öğretimi uygulamalarının değerlendirilmesi. Değerler Ë̆itimi Dergisi, 11(25), 7-31.

Aydın, M. Z. (2006) Ailede çocuğun ahlak eğitimi. Ankara: Nobel.

Aydın, M.Z. \& Gürler, Ș. (2014). Okulda değerler eğitimi. Ankara: Nobel.

Balat, U.G. (2012). Okul öncesinde değerler eğitimi ve etkinlik örnekleri. Ankara: Pegem.

Beil, B. (1996). Gutes Kind, Böses Kind. (C. Yorulmaz, Çev.) Ankara: Özkan.

Berens, A. E. \& Nelson, C. A. (2015). The science of early adversity: is there a role for large institutions in the care of vulnerable children? The Lancet, 386(9991), 388-398.

Büyüköztürk, Ş., Çakmak, E.K., Akgün, Ö.E., Karadeniz, Ş. \& Demirel, F. (2010). Scientific research methods. Ankara: Pegem.

Cebe, F. (2005). Sosyal hizmetler ve çocuk esirgeme kurumu yetiştirme yurtlarında barınan çocukların benlik saygısı, depresyon, kaygı skorlarının ailesi yanında kalan çocuklarla karşılaştırlması (Yüksek lisans tezi). İstanbul Üniversitesi Adli Tıp Enstitüsü, İstanbul.

Çağdaş, A. \& Şahin, Z. (2002). Çocuk ve ergende sosyal ve ahlak gelişimi. Ankara: Nobel.

Çalışkur, A. (2010). Psikolojide değerler ve gençlik. İstanbul: Papatya.

Dirican, R. (2013). 3-6 yaş grubu çocuklarına yönelik yayımlanan resimli hikaye kitaplarının bazı temel değerler açısından incelenmesi (Yüksek lisans tezi). Gazi Üniversitesi Eğitim Bilimleri Fakültesi, Ankara.

Erkan, G. (1995). Korunmaya muhtaç çocuklar: çocuk yuvalarında bir araştırma. Sosyal Hizmet, 24-78.

Gibbons, J. A. (2007). Sociological and symbolic family processes in the structure of orphanages in Egypt. International Journal of Sociology of the Family, 33(1), 199-217. 
Güçray Sonay, S. (1989). Çocuk yuvasında ve ailesi yanında kalan 9, 10, 11 yaş çocuklarının öz-saygı gelişimini etkileyen bazı faktörler (Doktora tezi). Hacettepe Üniversitesi Sosyal Bilimler Enstitüsü, Ankara.

Gül, R. (2013). Bir değer eğitimi olarak ilköğretim döneminde doğruluk ĕgitimi (Yüksek lisans tezi). Hitit Üniversitesi Sosyal Bilimler Enstitüsü, Çorum.

Gümüş, N. (2014). Çocuk evlerinde bulunan klz çocuklarının sosyalizasyonu üzerine niteliksel bir araştırma: Tekirdağ ili örneği (Yüksek lisans tezi). Maltepe Üniversitesi Sosyal Bilimler Enstitüsü, İstanbul.

Gürvardar, D. (2001). Yetiş̧tirme yurdunda yetişen çocuklar ile ana-baba yanında yetişen çocukların umutsuzluk düzeyinin karşılaştırılması. (Yüksek lisans tezi). Dokuz Eylül Üniversitesi Eğitim Bilimleri Enstitüsü, İzmir.

İnce, E. (2013). Kayseri ili'nde kurum bakımında olan 6-14 yaş grubu korunmaya muhtaç çocukların ruhsal uyum durumları (Yüksek lisans tezi). Erciyes Üniversitesi Sağlı Bilimleri Enstitüsü, Kayseri.

İşol Fidan, M. (2005). Sosyal hizmetler çocuk esirgeme kurumu çocuk yuvalarında barınan çocukların Wisc-R skorlarının değerlendirilmesi (Yüksek lisans tezi). Erişim adresi: https://tez.yok.gov.tr

Kalayc1, H. (2007). Yetiştirme yurtlarındaki çocuklarda sosyal dışlanma riski (Tokat ve Turhal örneği) (Doktora tezi). Sakarya Üniversitesi, Sosyal Bilimler Enstitüsü, Sakarya.

Kaler, S. R., \& Freeman, B. J. (1994). Analysis of environmental deprivation: Cognitive and social development in Romanian orphans. Journal of Child Psychology and Psychiatry, 35(4), 769-781.

Karatay, H 2011. Karakter eğitiminde edebi eserlerin kullanımı. Turkish Studies - International Periodical for The Languages, Literature and History of Turkish or Turkic. 6(1), 1398-1412.

Kemerkaya, G. (2012). Korunmaya muhtaç ilköğretim 6-8. sinif öğrencilerinin sosyalleşme becerilerinin incelenmesi (Yüksek lisans tezi). Aksaray Üniversitesi Sosyal Bilimler Enstitüsü, Aksaray.

Koşay, A. (2013). Çocuk yuvasında ve çocuk evinde kalan korunmaya muhtaç çocuklar ile ailesi yanında yaşayan çocukların sosyal becerilerinin karşılaştırılması (Yüksek lisans tezi). Dokuz Eylül Üniversitesi Eğitim Bilimleri Enstitüsü, İzmir.

Kozan, L. (2012). Korunmaya muhtaç çocukların din eğitimi (Yüksek lisans tezi). Frrat Üniversitesi Sosyal Bilimler Enstitüsü, Elazı̆̆g. 
Kutlu, M. (1992). Yetiştirme yurdunda ve ailesi yanında kalan ögrencilerin özsaygı ve düzeylerini etkileyen bazı değişkenler (Yüksek lisans tezi). İnönü Üniversitesi Sosyal Bilimler Enstitüsü, Malatya.

Milli Eğitim Bakanlığı (2013) Çocuk Gelişimi ve Eğitimi Ahlak Gelişimi. Erişim adresi: http://www.megep.meb.gov.tr/mte_program_modul/moduller_pdf/Ahlak\%20Geli\%C5\%9Fimi.pdf

Nalbant, Ş. (2016) Korunmaya muhtaç çocuklarda çocuk evleri bakım modelinin toplumsallaşmaya ilişkin rolü: Kayseri örneği (Yüksek lisans tezi). Erişim adresi: https://tez.yok.gov.tr

Özbey, S. (2012). Okul öncesi eğitim kurumuna devam eden 60-72 aylık çocuklarının sosyal beceri ve problem davranışlarının okul ve ev ortamına göre incelenmesi. Toplum ve Sosyal Hizmet Dergisi, 23(2), 21-32.

Öztürk, H. (2003). Ahlak eğitimi çerçevesinde ailede doğruluk eğitimi (Yüksek lisans tezi). Cumhuriyet Üniversitesi Sosyal Bilimler Enstitüsü, Sivas.

Öztürk, N. (2011). 61-72 aylık çocuklar için "Ahlâki değer yapısını belirleme ölçeği"”'nin geçerlik ve güvenirlik çalışması (Yüksek lisans tezi). Gazi Üniversitesi Eğitim Bilimleri Enstitüsü, Ankara.

Saçan, S. (2010). Sosyal hizmetler çocuk esirgeme kurumunda korunma altinda iken aile yanina döndürülen 6-18 yaş çocuk ve gençlerin duygusal ve davranış sorunlari; Kütahya ili örneği (Doktora tezi). Hacettepe Sağlık Bilimleri Enstitüsü, Ankara.

Sağ, V. (2003). Toplumsal değişim ve eğitim üzerine. Cumhuriyet Üniversitesi Sosyal Bilimler Dergisi, 27(1), 11-25.

Sapsağlam, Ö. (2016). Okul öncesi dönemde karakter ve değerler eğitimi teoriden uygulamaya. Ankara: Pegem.

Senemoğlu, N. (2015). Gelişim, öğrenme ve ögretim: Kuramdan uygulamaya. Ankara: Yarg1.

Sosyal Hizmetler Kanunu. (1983, 27 Mayıs). Resmi Gazete (Sayı: 18059).

Şenocak, H. (2005). Korunmaya muhtaç çocuklar: İstanbul yetiştirme yurtları üzerine bir alan araştırması (Doktora tezi). İstanbul Üniversitesi Sosyal Bilimler Enstitüsü, İstanbul.

Şimşek, Z., Erol, N., Öztop, D. \& Özer Özcan, Ö. (2008). Kurum bakımındaki çocuk ve ergenlerde davranış ve duygusal sorunların epidemiyolojisi; ulusal örneklemde karşıllaştırmalı bir araştırma. Türk Psikiyatri Dergisi. 19(3), 235-246. 
Terzi, E. E. (2009). Anasınıfina devam eden çocuklarda görülen davranış sorunlarının ögretmen görüşlerine göre incelenmesi (Yüksek lisans tezi). Gazi Üniversitesi Eğitim Bilimleri Enstitüsü, Ankara.

Turan, L. (2003). Korunmaya muhtaç çocukların umutsuzluk, suçluluk duyguları, benlik kavramları ve geçmişe iliş̧kin tutumlarının incelenmesi (Yüksek lisans tezi). Atatürk Üniversitesi Sosyal Bilimler Enstitüsü, Erzurum.

Tümkaya, S. (2005). Ailesi yanında ve yetiştirme yurdunda kalan ergenlerin umutsuzluk düzeylerinin karşılaştırılması. Türk Eğitim Bilimleri Dergisi, 3(4), 445- 459.

Uslu, R. (2011). Yararlandıkları hizmet modeline göre korunmaya muhtaç çocuklarda davraniş ve duygusal sorunlar (Yüksek lisans tezi). Dokuz Eylül Üniversitesi Eğitim Bilimleri Enstitüsü, İzmir.

Üstüner, S., Erol, N. \& Şimşek, Z. (2005). Koruyucu aile bakımı altındaki çocukların davranış ve duygusal sorunları. Çocuk ve Ergen Ruh Sağllğ $l$ Dergisi, 12(3), 130-140.

Yaka, Ş., Yalçın, D. \& Denizli, E. (2014). Okul öncesi eğitimde verilecek öncelikli değerlere ilişkin veli görüşleri. Değerler Eğitimi Dergisi, 12(28), 169-192.

Yalçın, A. (2011). Çocuk koruma kanunu kapsamında korunmaya muhtaç çocukların gelecek kaygllarının incelenmesi (Yüksek lisans tezi). Afyon Kocatepe Üniversitesi Sosyal Bilimler Enstitüsü, Afyonkarahisar.

Yalçın, H. (2010). Çocuk gelişimi. Ankara: Nobel.

Yazıc1, E. (2012). Korunmaya muhtaç çocuklar ve çocuk evleri. Mustafa Kemal Üniversitesi Sosyal Bilimler Enstitüsü Dergisi, 9(18), 499-525.

Yazıc1, E. (2013). Korunmaya muhtaç çocuklara yönelik sosyal hizmetler: kurum bakım hizmetinden yararlanmış bireyler üzerine bir araştırma (Doktora tezi). Dokuz Eylül Üniversitesi Sosyal Bilimler Enstitüsü, İzmir.

Yıldırım, A. (2005). Kurum Bakıminda olan ve ailesi ile birlikte kalan 13-18 yaş arası çocuklarda sürekli öfke ile depresyon düzeyleri arasındaki ilişkinin incelenmesi (Yüksek lisans tezi). Fırat Üniversitesi Sağlık Bilimleri Enstitüsü, Elazığ.

Yörükoğlu, A. (2007). Değişen toplumda aile ve çocuk. İstanbul: Özgür.

Yurdakul, A. (2016). Aile ve Sosyal Politikalar Bakanlığına bağlı kurum baklmında kalan çocuklarla koruyucu aile yanında kalan çocukların benlik saygisl ve psikososyal gelişimleri arasindaki farklılıkların incelenmesi (Yüksek lisans tezi). İstanbul Gelişim Üniversitesi Sosyal Bilimler Enstitüsü, İstanbul. 
Elif Yorgun Yasar, Saide Özbey

Yuvacı, Z. (2013). Okul öncesi değerler eğitimi uygulayan okullardan seçilen değerlerin ve etkinliklerin incelenmesi (Yüksek lisans tezi). Dumlupınar Üniversitesi Eğitim Bilimleri Enstitüsü, Kütahya. 
Extended Abstract

\section{Investigation of Moral Value Structures of 61-72 Months old Indigent Children According to Some Variables: The Case of Ankara}

Elif YORGUN YASAR, Corresponding Author, Teacher.

Minister of Family, Labor and Social Services.

E-mail: yorgun1992@hotmail.com

ORCID: 0000-0002-5430-9201

Saide ÖZBEY, Assoc. Prof.

Gazi University, Gazi Faculty of Education.

E-mail: saideozbey@gmail.com, sozbey@gazi.edu.tr

ORGID: 0000-0001-8487-7579

\section{Introduction}

The child, who is a small member of the society, is affected by the environment in which s/he lives, the environments $\mathrm{s} / \mathrm{he}$ enters, the people $\mathrm{s} / \mathrm{he}$ is in contact and the education s/he receives. As a result of the child's internalization of the values of the society in which s/he lives and the effort to adapt to the society, the values of $\mathrm{s} / \mathrm{he}$ possess are expected to parallel with the social values.

Love, respect, honesty, kindness, cleanliness and so on, are values approved by the society and the individuals with these values are expected to be respected in the society (Arabacı and Akgül, 2013; Dirican, 2013; Özbey, 2012; Öztürk, 2011; Sağ, 2003; Yazıc1, 2013; Yörükoğlu, 2007).

The most basic value group is considered as "moral values. From a young age, learning and and exhibiting correct behaviour in society will constitute the basis of exhibiting the moral behaviours that seen as appropriate in the society, so the childhood is regarded as the most productive period for the acquisition 
of basic values. With preschool education, children learn to share, solidarity, socialize and work together.

At the same time, it is aimed with the preschool education to acquire many moral values such as honesty, determination, helpfulness, self-confidence, respect, cooperation (Arabacı and Akgül, 2013; Aydın, 2006; Aydın and Gürler, 2014; Balat, 2012; Çağdaş and Şahin, 2002; Çalışkur, 2010; Gül, 2013; Karatay, 2011; Kozan, 2012; Sapsağlam, 2016; Senemoğlu, 2015; Yaka, Yalçın and Denizli, 2014)

The institution of family is where value education first starts. The family is a unique place of education for the child to gain behaviours, recognize values and internalize them. Due to the disadvantageous functions of some families, not every child has the chance to grow in their own family environment.

Regarding children in need of protection, the relevant court shall have the authority to decide with regard to custody and guardianship in accordance with the provisions of the Law on Agency for Social Services No. 2828 and Child Protection Law No 5395. When the protection decision is made the custody and care of the child could be given to the related institutions or could be given to a foster family under the supervision of the institutions established according to this law.

In the process, the which institutions providing care services for the protection of children have started to change from the ward type to the room system and began to transform the systems where children are accommodated in less crowded rooms.

For children in need for protection between 0-18 years of age Children's Homes institutions provide them with appropriate environments to build more permenent behaviors such as responsibility, sharing, self-confidence, help, courtesy and respectfulness by dealing with the children individually (Akbulut, 2006; Aydın, 2006; Beil, 1996; Ince, 2013; Kozan, 2012; Kutlu, 1992; SVET, 2013; The Social Services Law, 1983; Yazıc1, 2012)

\section{$\operatorname{Aim}$}

It is expected that the transition from barracks-type care services to child foster homes system for children in need of protection, and in such conditions looks like healthy family environment, would provide a positive impact on the personality development of children by arranging environments where less children stay together and individual care is existed. 
The aim of this study is to investigate the relationship between with some variables and moral structures of preschool children in need of protection.

Within the scope of the research, the following questions are sought:

- Are the moral values of children affected by the length of stay in the institution?

- Are the moral values of children affected by the situation of the reason for under protection?

- Are the moral values of children affected by being with their siblings/being separated with their siblings?

- Are the moral values of children affected by the situation of going to leave?

- Are the moral structures of children affected by the visitation situation?

\section{Method}

In the research, relational survey model, which is one of the general survey models, was used. The study group of the research consists of all children in need of protection between 61-72 months of age who are staying in Children's Homes in Ankara $(\mathrm{N}=48)$.

In the study, the data collection forms was filled by caregivers dealing with children in need of protection. Personal Information Form and Moral Value Structure Determination Scale used as data collection tools.

Personal Information Form: The personal information form prepared for children staying in child safe homes includes information about the reasons the children are under protection, the length of stay at the institution, being allowed to visit their families, visiting by relatives and being with their siblings/being separated with their siblings?

Moral Value Structure Determination Scale: Moral Value Structure Determination Scale developed by Öztürk (2011) was used to determine the moral value structures of preschool children. The internal consistency Cronbach's Alpha reliability coefficient calculated according to the answers given to children within the scope of this research is 0.979 for the children staying in the child safe homes. When these values are examined, it is concluded that the datas of children staying in Children's Homes are highly reliable for the sub-dimensions of the Moral Value Structure Determination Scale and the whole scale. 
In the analysis of the datas;

Children's scores obtained from Moral Value Structure Determination Scale;

- The Mann Whitney U test was used to compare situations that are; being allowed to visit their families and being with/being separated with their siblings?

- Kruskal Wallis test was used to compare the number of siblings, the reason behind their stay in the institution and the duration of stay in the institution.

\section{Results}

The scores of children staying in Children's Homes comes from justice, responsibility, kidness, helpfulness, sub-dimensions of respect and total scale scores showed a significant difference in favor of children staying 3 years and over in institution $(\mathrm{P}<0.05)$. The patience value structures of children show a significant difference in favor of children staying in the institution for 2 years.

Children's self-confidence and leadership value structures do not show a significant difference in terms of duration of stay in the institution. $(p>0.05)$.

According to the reasons for protection of children staying in child safe homes, the total scores of moral values do not show a significant difference $(\mathrm{P}>0.05)$.

It is seen that the moral values of children do not show a significant difference according to the to go their family being allowed. "( $(p>0.05)$.

Scores of children who participated in the study in terms of the possibility of visitation by relatives showed significant difference between the scores of the total scale in favour of the ones visited by relatives $(\mathrm{p}<0.05)$.

It is seen that the total scores of the moral value structure of the children do not show a significant difference according to being with their siblings/being separated with their siblings?". The value structures of charity and patience differ significantly in favor of children separated from their siblings.

\section{Discussion and Suggestions}

As a result of the study, it is seen that the scores get from Moral Value Structure Determination Scale are significantly higher in children whose duration of stay in the institution is 3 years and beyond. When other researches related to children in need of protection are examined, it is seen that they are mostly made 
with older age groups or children staying in orphanages (Cebe, 2005; Güçray, 1989; Kalayc1, 2007; Kemerkaya, 2012; Koşay, 2013; Yıldırım, 2005).

In this study, instead of crowded barracks type care, the Children's Homes type service model is addressed. In addition, 61-72 months old children are examined. In this study, the increase in the length of children staying in the Children's Homes and the increase in the value of moral structures, reveals the positive side of the Children's Homes system.

Factors such as caring for children individually, giving them the love and affection they need, having a fixed role model and satisfying the sense of trust with this updated model of foster homes are thought to play an important role in supporting children's value structures.

The scores of the children in need of protection from the Moral Value Structure Determination Scale in terms of the reasons behind the protection shows no significant difference.

In the literature research, the reasons behind taking the children under protection in foster homes at older ages indicate; low social skills scores, exhibiting problematic behaviors in school, having negative perspectives and negative self-esteem, and therefore all these factors impacting them with behavioral problems. (Amato and Keith, 1991; Kosay, 2013; Simsek, Erol, Oztop, Ozer Ozcan, 2008; Uslu, 2011)

In this study, it is seen that most of the 61-72 month old children in the study group stayed in institutions for 2 years or beyond.

Therefore, in this study, it is seen that children are much younger in the case of protection and they are taken to children's Homes care, not staying much in environments that may adversely affect their development. Thus moral value structures are not affected by the reasons they are under protection.

According to the results of the study, children's moral values were not affected by the condition of being allowed to visit their families. There is a significant difference in favor of those visited by relatives. When the literature is examined, it has been concluded that condition of visiting by relatives of children in Children's Homes care, affect children positively (Tümkaya, 2005; Üstüner, Erol, Şimşek, 2005; Yıldırım, 2005; Yurdakul, 2016).

Acquiring and maintaining the concepts of moral value in children requires a process. Since the children in need of protection visit their families on shortterm leave, it is considered that the condition of being allowed to visit their families is not influential on the moral value structures. 
As a result of the study, it is seen that children who are not visited by their relatives are affected negatively. With this reached result, the importance of the children being visited by their families and feeling the support of the family during their stay in the child safe homes was revealed.

According to the results of the research, there is a significant difference in benevolence and sub-dimensions of patient in favor of who are separated from their siblings. As a result of this, it can be said that the children who stay in the same house after a while feel like siblings and longing for their own siblings increases their benevolence towards other children.

Likewise, it is thought that children who are separated from their siblings cannot be provided with appropriate conditions in Children's Homes care and start to live by accepting this situation after a while, but feeling of being separated and longing causes higher values of patience.

In the literature research, it was concluded that the longing of siblings increases with the ones separated from their siblings and the mental status of who met with their siblings was more positive (Gümüş, 2014; İnce, 2013). There is no significant difference in other sub-dimensions that can be interpreted as the positive effect of regular meeting of children staying in Children's Homes with their siblings.

In the light of these results, the following suggestions may be presented;

The families and relatives of the children should be made aware of the fact that children should be able to communicate with their visitors in a better organized way. In this context, various activities can be planned in order to make the parent-child interaction more qualified during the meeting with parents.

Social awareness should be increased in order to prevent failed marriages and to reduce divorces and put necessary guidance and support activities that could be carried out to ensure family integrity.

Studies should be made to ensure that children staying in Children's Homes communicate with their siblings more efficiently and positively. At the stage of determining social activities, attention should be paied to make the siblings spend as much time as possible by arranging the houses where the sperated sibling are living in. Also, siblings staying in different houses should also be brought together in family visitations.

As a result of the fact that the moral values of children staying in Children's Homes for 3 years and beyond were affected positively, the importance of 
changing from barracks type care model to foster home model was emphasized in the research. The quality of the Children's Homes system should also be increased.

The points where the child homes ystem fall short to support children should be identified, further studies should be done on this age group in other provinces and other institutions and the necessary arrangements should be supported to develop Children's Homes system in a positive way. 